\title{
Analisis Tingkat Kesehatan Bank Umum Syariah Di Indonesia dengan Menggunakan Metode Risk-based Bank Rating tahun 2014-2016
}

\author{
Sri Rokhlinasari, Evi Eriyanti \\ Program studi Perbankan Syariah FSEI IAIN Syekh Nurjati Cirebon \\ e-mail: evieriyanti20@gmail.com; srirokh@yahoo.com
}

\begin{abstract}
Abstrak
Penelitian ini bertujuan untuk menganalisis kondisi kesehatan Bank Umum Syariah Di Indonesia dan Membandingkan kondisi kesehatan Bank Syariah Mandiri dan Bank Muamalat Indonesia, metode penelitian yang digunakan adalah analisis deskriptif dengan pendekatan kuantitatif. Pengukuran kesehatan keuangan dilakukan dengan metode Risk-Based Bank Rating berdasarkan Surat Edaran Otoritas Jasa Keuangan No. 10/SEOJK.03/2014. Berdasarkan hasil pengukuran kesehatan Bank Umum Syariah secara keseluruhan yang diukur dari aspek Profil Risiko, Rentabilitas dan Permodalan pada tahun 2014-2016 yang meliputi rasio NPF, FDR, ROA, NOM, dan CAR. Dapat diperoleh kesimpulan kesehatan Bank Umum Syariah untuk Profil Risiko yang di ukur dengan rasio NPF dan FDR, untuk rasio NPF tahun 2014-2016 dalam keadaan sehat dan untuk rasio FDR dalam keadaan cukup sehat. Rentabiltas yang di ukur dengan rasio ROA dan NOM dalam keadaan kurang sehat pada tahun 2014-2015 dan pada periode 2016 dalam keadaan cukup sehat, rasio NOM dari tahun 2014-2016 Bank Umum Syariah dalam keadaan tidak sehat, untuk Permodalan yang di ukur dalam rasio CAR tahun 2014-2016 dalam keadaan sangat sehat.Pada analisis perbandingan menggunakan Independent Sample t-test yang diukur dari dari aspek Profil Risiko, Good Corporate Governance, Rentabilitas dan capital menunjukkan bahwa tidak terdapat perbedaan yang signifikan antara kesehatan keuangan Bank Syariah Mandiri dan Bank Muamalat Indonesia.
\end{abstract}

Kata Kunci :Kesehatan Keuangan bank, Metode Risk-Based Bank Rating

\begin{abstract}
Abstack
The purpose of this reserch to analyze the condition of healty the common bank sharia mandiri and bank muamalat indonesia. This methode reserch using the descriptive analyze with approach quantitative. The meansuring of healty finances with the method Risk-Based Bank Rating according letter Otoritas Jasa Keuangan No.10/SEOJK.03/2014. According the result of the healty common bank sharia, over all the measured the aspect Risk Profile, Rentabilitas and Capital in 2014-2016. With cover the ratio NPF, FDR, ROA, NOM, and CAR. Can get the conclusion the healty of common bank sharia for Risk Profile measured by the ratio NPF and FDR, for the ratio NPF in 2014-2016 in the good healty and for ratio FDR in the quite healty. Rentabilitas that measured with ratio ROA and NOM in bad healty 20142015, in 2016 the quite healty, the NOM ratio 2014-2016 period common bank sharia in bad healty and for Capital the measured in the ratio CAR in 2014-2016 is very good healty.This analyze than comparision using Independent Sample t-Test that measured from aspect of Risk Profile, Good Corpotare governance, Rentabilitas and Capital, in dirate there is no a significant differences between the financial healty in bank sharia mandiri and bank muamalat indonesia.
\end{abstract}

Keywords: the Healty financial of Bank, Risk-based Bank Rating method 


\section{Pendahuluan}

Perbankan adalah suatu industri yang bergerak dibidang keuangan yang berperan dalam kemajuan ekonomi suatu negara. Perbankan adalah lembaga yang memiliki peran intermediasi atau sebagai perantara antara pihak yang kelebihan dana (surplus spending unit) dengan pihak yang kekurangan dana (defisit spending unit) yang secara tidak langsung membantu perputaran uang dalam masyarakat ${ }^{1}$. Bank menurut Undang-Undang perbankan pasal 1 Nomor 21 tahun 2008 tentang perbankan bank adalah badan usaha yang menghimpun dana masyarakat dalam bentuk simpanan dan menyalurkannya kepada masyarakat dalam bentuk kredit dan atau bentuk-bentuk lainnya dalam rangka meningkatkan taraf hidup rakyat banyak.

Bank terdiri dari dua jenis yaitu bank konvensional dan bank syariah. Bank konvensional adalah bank yang menjalankan kegiatan usahanya secara konvensional. Dan bank syariah adalah bank yang dalam menjalankan kegiatannya berdasarkan prinsip syariah yang terdiri dari Bank Umum Syariah (BUS) dan Bank Pembiayaan Rakyat Syariah (BPRS). BUS adalah bank syariah yang kegiatanya memberikan jasa dalam lalu lintas pembayaran secara prinsip syariah ${ }^{2}$. Kegiatan operasional bank akan terus berjalan apabila kebutuhan dana bank dapat terpenuhi, oleh karena itu bank harus mampu menarik kepercayaan masyarakat untuk menyimpan uang mereka di bank.

Kepercayaan masyarakat dapat dibangun dengan bentuk transparansi dari lembaga perbankan, baik dari segi laporan keuangan maupun keadaan kesehatan bank yang dipublikasikan. Lembaga perbankan Indonesia sempat merasakan kehilangan kepercayaan masyarakat terhadap lembaga perbankan. Masyarakat Indonesia pada

\footnotetext{
${ }^{1}$ Komang Mahenda Pramana, Luh gede sri artini, Analisis tingkat kesehatan bank (pendekatan RGEC) pada PT. Bank Danamon Indonesia TBK, EJurnal Manajemen Unud, 2014, V01.5, No.6. h. 3850

${ }^{2}$ Rizal Yaya, dkk. Akuntansi Perbankan Syariah Teori dan Praktik Kontemporer, (Jakarta: Salemba Empat, 2014). h. 48
}

waktu itu merasa ragu untuk menyimpan uang mereka di bank dan menarik uang mereka yang telah mereka simpan di bank.

Situasi dimana masyarakat kehilangan kepercayaan pada lembaga perbankan tersebut terjadi pada saat Indonesia mengalami krisis moneter yang terjadi pada tahun 1998. Krisis moneter ini terjadi dimulai pada pertengahan tahun 1997. Kesulitan likuidasi yang dialami lembaga perbankan akibat merosotnya nilai tukar rupiah terhadap dollar AS merupakan pemicu krisis yang dialami pada waktu itu. Melemahnya nilai tukar rupiah tersebut menyebabkan perbankan Indonesia sulit untuk menjalankan kewajibannya sebagai lembaga keuangan negara. Keadaan perbankan yang semakin tidak sehat menyebabkan situasi yang dialami oleh perbankan semakin memburuk. ${ }^{3}$

Indonesia kembali mengalami krisis pada tahun 2008 yang memberikan dampak negatif terhadap perekonomian negara. Indonesia pada waktu itu mengalami perlambatan pertumbuhan ekonomi dimana pada tahun 2007 laju pertumbuhan ekonomi negara mencapai $6,7 \%$ dan pada tahun 2008 hanya tumbuh $6,1 \%$. Dampak lain yang ditimbulkan dari perlambatan pertumbuhan ekonomi tersebut adalah menurunnya kinerja neraca pembayaran, tekanan pada nilai tukar rupiah dan dorongan pada laju inflasi.

Bank Indonesia (BI) sebagai otoritas moneter yang mempunyai independensi dari pemerintah mempunyai kewajiban menjaga stabilitas moneter serta mengeluarkan kebijakan-kebijakan yang dapat meminimalisir dampak dari krisis global. Bank Indonesia telah menerapkan beberapa kebijakan, yakni:Kebijakan dalam sektor perbankan adalah meningkatkan kapasitas pelayanan industri perbankan syariah. Sistem perbankan syariah terbukti lebih tahan terhadap hantaman krisis. Sistem perbankan ini juga sudah mulai digiatkan oleh negara-

\footnotetext{
${ }^{3}$ Hening Asih Widyaningrum, Suhandak, Topowijono, Analisis Tingkat Kesehatan Bank Menggunkan Risk Based Bank Rating (RBBR). Sub Sektor Perbankan tahun 2012. Jurnal Administrasi Bisnis Vol.9 No.2 April 2014. 2
} 
negara non-muslim seperti Inggris, Italia, Hong Kong, China, Malaysia, dan Singapura. Bahkan menurut anggota Komite Ahli Bank Indonesia, perbankan syariah tetap stabil di saat krisis global berlangsung dikarenakan perbankan syariah merupakan pilihan yang komprehensif, progresif, dan menguntungkan. Seiring dengan semakin dalamnya tekanan krisis global, sejak semester II-2008, kebijakan perbankan ditujukan pada upaya mengurangi imbas krisis global pada perbankan domestik. ${ }^{4}$

Bank Syariah dapat membuktikan ketahanannya terhadap krisis yang yang dihadapi pada tahun 1997-1998, Bank Syariah di Indonesia secara konsisten telah menunjukan perkembangannya dari waktu ke waktu, Bank syariah tetap kokoh menunjukan ketangguhannya sebagai salah satu pilar penyokong stabilitas sistem keuangan nasional. Bank syariah pertama kali berdiri adalah Bank Muamalat Indonesia (BMI). Bank yang melakukan kegiatan usaha berdasarkan prinsip syariah terus meningkat Bank Umum Syariah tercatat yang pada akhir tahun 2009 berjumlah 6 BUS bertambah 5 BUS dimana 3 BUS merupakan hasil konversi Bank Umum Konvensional dan 2 BUS hasil Spin off dari Unit Usaha Syariah (UUS) sehingga jumlah UUS pada tahun 2010 terdapat 23 UUS dan 11 BUS, angka tersebut bertahan sampai bulan juli 2014. Jumlah BUS bertambah menjadi 12 BUS akibat 1 UUS spin off sehingga UUS di tahun 2014 terdapat 22 UUS dan 12 BUS bertahan hingga Sampai bulan juni tahun 2015, pada akhir desember 2016 jumlah BUS menjadi 13 karena 1 UUS kembali Spin off, jumlah UUS menjadi 21 Unit $^{5}$.

Sektor perbankan merupakan sektor yang sangat maju, yang kemajuannya diiringi dengan berbagai kemajuan teknologi

\footnotetext{
${ }^{4}$ Purna, dkk, "Perekonomian Indonesia Tahun 2008 Tengah Krisis Keuangan Global”, artikel diakses pada Tanggal 16 Februari 2017 dari www.setneg.go.id

${ }^{5}$ Otoritas Jasa Keuangan, Statistik Perbankan Syariah desember 2016. Di akses pada tanggal 20 Maret 2017 dari www.ojk.go.id
}

dan semakin meningkatnya kesadaran pendidikan dan ilmu pengetahuan. Tingkat kesehatan bank dapat dinilai dalam beberapa indikator salah satu indikator yang disajikan adalah berupa laporan keuangan bank yang bersangkutan. Berdasarkan laporan keuangan, dapat dihitung sejumlah rasio keuangan yang bisa dijadikan dasar penilaian tingkat kesehatan bank. Oleh karena itu meningkatnya inovasi dalam produk, jasa, dan aktivitas perbankan syariah berpengaruh pada peningkatan kompleksitas usaha dan profil risiko bank yang apabila tidak diimbangi dengan penerapan manajemen risiko yang memadai dapat menimbulkan berbagai permasalahan mendasar pada bank maupun terhadap sistem keuangan secara keseluruhan.

Pengaruh perbankan bagi perekonomian sangat strategis dan dominan, bank telah menjadi lembaga yang turut memengaruhi perkembangan perekonomian suatu negara. Prestasi maupun kinerja yang buruk dari perbankan akan dengan sendirinya turut memberikan andil bagi kinerja, maupun pertumbuhan ekonomi suatu negara, tumbuh kembang dan sehatnya perekonomian suatu negara sebagian besar tergantung pada kesehatan perbankaan dinegara tersebut. Kesehatan bank disatu sisi dan kepiawaian bank mewujudkan kinerja yang optimal pada sisi yang lain merupakan dua unsur yang saling menunjang kesehatan perekonomian suatu negara.

Penilaian kesehatan bank dapat ditinjau dari berbagai aspek yang bertujuan untuk menentukan apakah bank tersebut dalam kondisi yang sehat, cukup sehat, kurang sehat atau tidak sehat. Menurut bank of sattlement, bank dapat dikatakan sehat apabila bank tersebut dapat melakukan kontrol terhadap aspek modal, aktiva, rentabilitas manajemen dan aspek likuiditasnya. Pengertian kesehatan bank menurut bank indonesia sesuai UndangUndang RI No. 7 tahun 1992 tentang perbankan pasal 29 adalah bank dikatakan sehat apabila bank tersebut memenuhi ketentuan kesehatan bank, dengan memperhatikan aspek permodalan, kualitas 
manajemen, kualitas rentabilitas, likuiditas, solvabilitas dan aspek lain yang berhubungan dengan usaha bank.

Kesehatan atau kondisi keuangan dan non keuangan bank merupakan kepentingan semua pihak terkait, baik pemilik, manajemen bank, bank pemerintah melalui bank Indonesia dan pengguna jasa bank. Dengan diketahuinya kondisi suatu bank dapat digunakan oleh pihak-pihak tersebut untuk mengevaluasi kinerja bank dalam menerapkan prinsip kehati-hatian, kepatuhan, terhadap ketentuan yang berlaku dan manajemen risiko. Perkembangan industri perbankan, terutama produk dan jasa yang semakin kompleks dan beragam akan meningkatkan eksposure risiko yang dihadapi bank. Perubahan eksposure risiko bank dan penerapan manajemen profil risiko bank yang selanjutnya berakibat pada kondisi bank secara keseluruhan. ${ }^{6}$

Menyadari arti pentingnya kesehatan suatu bank bagi pembentukan kepercayaan dalam dunia perbankan serta untuk melaksanakan prinsip kehati-hatian (prudential banking) dalam dunia perbankan, maka Bank Indonesia perlu menerapkan aturan tentang kesehatan bank. Dengan adanya aturan tentang kesehatan bank, perbankan diharapkan selalu dengan kondisi sehat, sehingga tidak akan merugikan masyarakat yang berhubungan dengan perbankan. Bank yang peroperasi dan berhubungan dengan masyarakat diharapkan hanya bank yang betul betul sehat. Aturan tentang kesehatan bank yang diterapkan oleh bank Indonesia mencangkup berbagai aspek dalam kegiatan bank, mulai dari penghimpunan dana sampai dengan penggunaan dan penyaluran dana. ${ }^{7}$

Perkembangan metodologi penilaian kondisi kesehatan bank bersifat dinamis sehingga sistem penilaian kesehatan bank senantiasa disesuaikan agar lebih

\footnotetext{
${ }^{6}$ Sigit Triandara dan Totok Budisantoso, Bank dan Lembaga Keuangan Lain, (Jakarta: Salemba Empat, 2008). h.53

${ }^{7}$ Sigit Triandara dan Totok Budisantoso, Bank dan Lembaga Keuangan Lain, (Jakarta: Salemba Empat, 2008). h.52
}

mencerminkan kondisi bank yang sesungguhnya, baik saat ini maupun waktu yang akan datang. Terdapat beberapa metode yang dapat digunakan dalam menilai tingkat kesehatan perbankan syariah salah satunya adalah peraturan Bank Indonesia Nomor 9/24/DPbS tanggal 30 Oktober 2007 yang dalam penilaiannya menggunakan pendekatan CAMELS (Capital, Assets Quality, Management, Earnings, Liquidity, and Sensitivity to Market Risk). Peraturan ini digantikan dengan peraturan yang dikeluarkan oleh Bank indonesia dan Otoritas Jasa Keuangan yang baru.

Sehubungan dengan berlakunya Peraturan Otoritas Jasa Keuangan Nomor 08/POJK.03/2014 tentang Penilaian Tingkat Kesehatan Bank Umum Syariah dan Unit Usaha Syariah, Peraturan Bank Indonesia Nomor 13/23/PBI2011 tentang Penerapan Manajemen Risiko bagi Bank Umum Syariah dan Unit Usaha Syariah. Sesuai peraturan Otoritas Jasa Keuangan tentang penilaian Tingkat Kesehatan Bank Umum Syariah, bank wajib melakukan penilaian sendiri Tingkat Kesehatan Bank dengan pendekatan Risk-based Bank Rating. Dengan komponen penilaian mencangkup faktor profil risiko (risk profile), good corporate governance (GCG), Rentabilitas (earnings), dan permodalan (Capital) untuk mengetahui hasil tingkat kesehatan bank ${ }^{8}$.

Menurut SEOJK No.10/2014 menjelaskan bahwa profil risiko merupakan penilaian terhadap risiko inhern dan kualitas penerapan manajemen risiko dalam aktivitas operasional bank. Risiko yang wajib dinilai terdiri atas 10 jenis risiko yaitu risiko kredit, risiko pasar, risiko likuiditas, risiko operasional, risiko hukum, risiko stratejik, risiko kepatuhan, risiko reputasi, risiko imbal hasil, dan risiko investasi. faktor kedua yang menjadi dasar penilaian adalah faktor Good Coporate Governance bagi bank umum syariah merupakan penilaian terhadap kualitas manajemen bank atas pelaksanaan lima prinsip good corporate governance

\footnotetext{
${ }^{8}$ Surat Edaran Otoritas Jasa Keuangan No.10/SEOJK.03/2014. Diakses tanggal 13 Oktober 2016
} 
yaitu transparansi, akuntabilitas, pertanggungjawaban, profesional dan kewajaran.

Rentabilitas merupakan faktor selanjutnya yang digunakan dalam pengukuran tingkat kesehatan bank umum syariah. Penilaian faktor Rentabilitas meliputi evaluasi terhadap kinerja Rentabilitas, sumber-sumber Rentabilitas, kesinambungan (sustainability) Rentabilitas, manajemen Rentabilitas dan pelaksanaan fungsi sosial. Penilaian faktor permodalan atau Capital meliputi evaluasi terhadap kecukupan modal dan kecukupan pengelolaan permodalan. Dalam melakukan perhitungan permodalan, bank umum syariah mengacu pada ketentuan yang berlaku mengenai kewajiban penyediaan modal minimum dan juga dengan profil risiko.

Penelitian ini menggunakan metode analisis deskriptif pendekatan kuantitatif dengan uji independent sample t-test, sample untuk analisis deksriptif 13 Bank Umum Syariah Di Indonesia, uji perbandingan 2 bank Umum syariah yaitu Bank Syariah Mandiri dan Bank Muamalat Indonesia tahun 2014-2016.

Penelitian ini bertujuan untuk signifikansi keilmuan tentang kesehatan bank syariah yang ada di indonesia. Dengan pendekatan melalui peraturan baru yang dikeluarkan oleh Otoritas Jasa Keuangan Risk-based Bank Rating.

\section{Pembahasan}

\section{Penilaian Faktor Profil Risiko (Risk Profile)}

Penilaian faktor profil risiko merupakan penilaian terhadap risiko inhern dan kualitas penerapan Manajemen Risiko dalam aktivitas operasional bank. Risiko yang wajib dinilai terdiri dari 10 jenis risiko yaitu risiko kredit, risiko pasar, risiko likuiditas, risiko operasional, risiko hukum, risiko sratejik, risiko kepatuhan, risiko reputasi, risiko imbal hasil, dan risiko investasi.

kegiatan bisnis bank, baik yang dapat dikuantifikasikan maupun yang tidak, yang berpotensi mempengaruhi posisi keuangan bank, karakteristik risiko inhern bank ditentukan oleh faktor internal dan eksternal, antara lain strategi bisnis, karakteristik bisnis, kompleksitas produk dan aktivitas bank, industri dimana bank melakukan kegiatan usaha, serta kondisi makro ekonomi.

Risiko kredit adalah risiko akibat kegagalan nasabah atau pihak lain dalam memenuhi kewajiban kepada bank sesuai dengan perjanjian yang disepakati. Risiko kredit pada umumnya melekat pada seluruh aktivitas penanaman dana yang dilakukan oleh bank yang kinerjanya bergantung pada kinerja pihak lawan, penerbit, atau kinerja peminjam dana.

Risiko likuiditas adalah risiko akibat ketidak mampuan bank untuk memenuhi kewajiban yang jatuh tempo dari sumber pendanaan arus kas atau aset likuid berkualitas tinggi yang dapat diagunkan, tanpa mengganggu aktivitas dan kondisi keuangan bank.

\section{Penilaian Faktor Good Corporate Governance}

Corporate governance atau tata kelola perusahaan adalah sistem yang dipergunakan dalam mengarahkan dan mengendalikan kegiatan bisnis perusahaan. Corporat governance ini juga mengandung pengertian mengenai pengaturan atas pembagian tugas dan tanggungjawab di antara para pihak atau para "key player" yang berpartisipasi dan memiliki kepentingan yang berbeda-beda dalam perusahaan. Para pihak yang berkepentingan atas pengarahan pengendalian perusahaan meliputi: dewan direksi, para manajer, para pemegang saham dan stakeholders lainnya. Oleh karena itu corporategovernance juga dapat didefinisikan sebagai seperangkat hubungan antara dewan komisaris, dewan direksi, atau board of execitive derektors, stakeholder, dan pemegang saham suatu perusahaan ${ }^{9}$.

\footnotetext{
${ }^{9}$ Masyhud Ali, Manajemen Risiko, (Jakarta: PT. RajaGrafindo Persada, 2006). 334
} 
Penilaian Faktor Good Corporate Governance bagi bank umum syariah merupakan penilaian terhadap kualitas manajemen bank atas pelaksanaan 5 prinsip Good Corporate Governance yaitu transparansi, akuntabilitas, pertanggugjawaban, profesional, dan kewajaran. Prinsip-prinsip Good Corporate Governance dan fokus penilaian terhadap pelaksanaan prinsip-prinsip Good Corporate Governance tersebut berpedoman pada ketentuan Good Corporate Governance yang berlaku bagi bank umum syariah dengan memperhatikan karakteristik dan kompleksitas usaha bank.

\section{Penilaian Faktor Rentabilitas}

Penilaian Faktor Rentabilitas meliputi evaluasi terhadap rentabilitas, sumbersumber rentabilitas, kesinambungan rentabilitas, manajemen rentabilitas dan pelaksanaan fungsi sosial. Penilaian dilakukan dengan mempertimbangkan tingkat, trend, struktur, stabilitas, rentabilitas bank umum syariah, dan perbandingan kinerja bank umum syariah dengan kinerja grup, baik melalui analisis aspek kuantitatif maupun kualitatif.

\section{Penilaian Faktor Permodalan}

Penilaian Faktor Permodalan meliputi evaluasi terhadap kecukupan modal dan kecukupan pengelolaan permodalan. Dalam melakukan perhitungan permodalan, bank umum syariah mengacu pada ketentuan yang berlaku mengenai kewajiban penyediaan minimum bagi bank umum syariah. Selain itu, dalam melakukan penilaian kecukupan modal, bank umum syariah juga harus menguatkan kecukupan modal dengan profil risiko. Semakin tinggi risiko, semakin besar modal yang harus disediakan untuk mangantisipasi risiko.

\section{Penelitian Terdahulu}

Dalam penelitian yang akan dilakukan, penulis menjadikan beberapa penelitian terdahulu sebagai acuan dan referensi diantaranya sebagai berikut :
Sandhy Dharmapermata Susanti (2015), dalam penelitianya mengkaji tentang analisis kesehatan bank. Penelitian ini bertujuan untuk mengatahui tingkat kesehatan bank ditinjau dari faktor RiskBased Bank Rating. Penilaian ini dilakukan pada bank yang menerbitkan laporan keuangannya selama tahun 2011-2013 dan bank tersebut adalah Bank Mandiri, Bank Negara Indonesia, Bank Tabungan Negara, Bank Rakyat Indonesia, dan bank OCBC NISP. Penelitian ini malakukan penilaian terhadap empat faktor RBBR, faktor Risk Profile melalui rasio NPL dan LDR, faktor Good Corporate Governance, faktor Earning melalui Rasio ROA dan NIM, dan faktor Capital melalui rasip CAR. Hasil penelitian menunjukan pada periode 2011-2013 keseluruhan bank yang diteliti memiliki predikat sangat sehat. Faktor Risk Profile menunjukan NPL bank dibawah 5\% dan mayoritas LDR bank berpredikat cukup sehat. Faktor Good Coporate Governance menunjukan bank mendapat predikat sangat baik. Faktor Earning menunjukan ROA bank lebih dari 1,5\% dan NIM bank lebih dari $3 \%$. Faktor Capital menunjukan CAR bank lebih dari $12 \%$ sehingga mampu memenuhi kewajiban penyediaan modal minimum sebesar $8 \%$.

Penelitian dari Hening Asih Widyaningrum (2014), dalam penelitiannya mengkaji tentang analisis tingkat kesehatan bank. Penelitian ini bertujuan untuk mengetahui tingkat kesehatan bank yang terdaftar di Bursa Efek Indonesia dalam sub sektor perbankan tahun 2012, penilaian dengan menggunakan metode Risk-Based Bank Rating terdiri dari empat faktor risk profil, Good Corporate Governance, earning, dan Capital dari setiap bank.penelitian menggunakan dua faktor dari empat faktor yang ada yakni dengan faktor earning dengan rasio Return On Asset (ROA) dan Net Interest Margin (NIM), serta Capital dengan Capital Edequacy Ratio (CAR). Hasil dari penelitian yang diperoleh dari Return On Asset menunjukan masih terdapat bank yang tidak sehat dengan nilai Return On Asset di bawah 1,25\%. Penilaian 
Net Interest Margin menunjukan keseluruhan bank yang menjadi sampel penelitian dapat digolongkan kedalam bank sehat. Penilaian terhadap faktor Capital dengan Capital Edequacy Ratio menunjukan hasil yang positif pada setiap bank, secara keseluruhan setiap bank memiliki nilai Capital Edequacy Ratio di atas $10 \%$ sehingga masuk kedalam bank sehat.

Berdasarkan telaah pustaka dan penelitian terdahulu di atas, hipotesis yang diajukan dalam penelitian ini adalah terdapat perbedaan yang signifikan antara kesehatan Bank Syariah Mandiri dan Kesehatan Bank Muamalat Indonesia.

\section{Hasil penelitian}

\section{Analisis Deskripsi Data Uji Beda}

Deskripsi pada data yang dianalisis perlu disampaikan untuk memberikan gambaran tentang penelitian, variabel yang digunakan adalah menggunakan metode Risk-based Bank Rating. Analisis deskripsi dilakukan berdasarkan kriteria yang telah ditentukan, maka pengambilan sampel yang digunakan dalam penelitian ini adalah 2 Bank Umum Syariah yang kemudian di rataratakan untuk Dibandingkan. Untuk menjawab tujuan penelitian, dilakukan analisis rasio keuangan pada masing-masing bank dengan menggunakan metode Riskbased Bank RatingDimana Profil Risiko yaitu risiko kredit dengan rasio NPF (Non Performing Financing) dan rasio likuiditas dengan rasio FDR (Financing to Deposite Rasio), Good Corporate Governance Melalui Penilaian Sendiri (Self Assesment), Rentabilitasdengan menggunakan rasio ROA (Return On Asset) dan NOM (Net Operation Margin) dan Permodalan dengan menggunakan rasio CAR (Capital Adequacy Ratio). Yaitu analisis perbandingan kinerja antar bank melalui kesehatan bank.

\section{Analisis Rasio Keuangan Bank Syariah Mandiri}

\section{a. Profil Risiko}

Penilaian faktor profil risiko merupakan penilaian terhadap risiko inhern dan kualitas penerapan Manajemen Risiko dalam aktivitas operasional bank. Penilaian untuk profil risiko bank terbagi menjadi beberapa alternatif rasio diantara yang penulis pilih adalah NPF (Non Performing Financing) dan FDR (Financing To Deposit Rasio).

\section{1) NPF (Non Performing Financing)} merupakan rasio untuk mengukur tingkat pembiayaan bermasalah terhadap total pembiayaan yang dihadapi oleh Bank Syariah. Semakin tingi rasio NPF menunjukan kualitas pembiayaan bank syariah yang semakin buruk terhadap pembiyaan yang dihadapi bank. tahun 20142016.

Tabel. Perhitungan Rasio NPF Bank Syariah Mndiri (Dalam Miliran Rupiah)

\begin{tabular}{|c|c|c|c|}
\hline Tahun & $\begin{array}{c}\text { Total } \\
\text { Pembiayaan }\end{array}$ & $\begin{array}{c}\text { Pembiayaan } \\
\text { Bermasalah }\end{array}$ & $\begin{array}{c}\text { Rasio } \\
\text { NPF (\%) }\end{array}$ \\
\hline 2014 & 49.133 & 2.107 & 4,29 \\
\hline 2015 & 51.090 & 2.069 & 4,05 \\
\hline 2016 & 55.580 & 1.739 & 3,13 \\
\hline
\end{tabular}

Sumber: Laporan Keuangan Tahunan Bank Syariah Mandir tahun 2016

Setelah melakukan analisis antara total pembiayan dengan pembiayaan bermasalah, maka selanjuttnya menghitung nilai NPF Bank Syariah Mandiri, NPF (Non Performing Financing) periode 31 desember 2014 sebesar 4,29\%, tahun 2015 turun ke nilai 4,05\%, kemudian tahun 2016 kembali mengalami penurunan menjadi $3,13 \%$. Hal ini menunjukan bahwa dari tahun 2014 hingga 2016 rasio NPF BSM mengalami penurunan yang signifikan. Semakin menurunnya rasio NPF menandakan bahwa BSM mampu menunjukan Kualitas pembiayaan yang dilakukan BSM semakin baik, dengan menurunnya rasio NPF setiap tahunnya. BSM mendapat predikat penilaian rasio NPF dengan predikat "Sehat" dalam mengelola pembiayaan terhadap pembiayaan bermasalah yang dihadapi.

\section{2) FDR (Financing to Deposite rasio)}

FDR merupakan rasio yang digunakan untuk mengukur tingkat likuiditas suatu bank, dengan cara membandingkan antara pembiayaan yang disalurkan dengan dana 
yang dihimpun dari masyarakat sehingga dapat diketahui kemampuan bank dalam membayar kewajiban jangka pendeknya. Semakin tinggi rasionya maka semakin rendah kemampuan likuiditas bank tersebut.

Tabel. Perhitungan Rasio FDR Bank Syariah Mandiri (Dalam Miliaran Rupiah)

\begin{tabular}{|c|c|c|c|}
\hline Tahun & $\begin{array}{c}\text { Total } \\
\text { Pembiayaan }\end{array}$ & $\begin{array}{c}\text { Total Dana } \\
\text { Pihak Ketiga }\end{array}$ & $\begin{array}{c}\text { Rasio } \\
\text { FDR }(\%)\end{array}$ \\
\hline 2014 & 49.133 & 59.821 & 82,13 \\
\hline 2015 & 51.090 & 62.113 & 82,25 \\
\hline 2016 & 55.580 & 69.950 & 79,45 \\
\hline
\end{tabular}

Sumber: Laporan Keuangan Tahunan Bank Syariah Mandir tahun 2016

Setelah melakukan analisis antara total pembiayaan dengan jumlah DPK, maka selanjutnya menghitung nilai FDR BSM, FDR (Financing to Deposit Ratio) BSM periode akhir desember 2014 sebesar $82,13 \%$, tahun $201582,25 \%$, kemudian tahun 2016 menjadi 79,43\%. Dari tahun 2014 sampai 2016 kinerja BSM semakin Sehat ditandai dengan menurunnya rasio FDR yang menunjukan bahwa BSM dapat memenuhi atau mampu membayar kewajiban jangka pendeknya dengan semakin baik, predikat untuk penilaian rasio FDR adalaah "Sehat" BSM mampu mengelola kewajiban jangka pendeknya dengan baik.

\section{b. Good Corporate Governance}

Sebagai wujud komitmen Bank Syariah Mandiri terhadap Surat Edaran Otoritas Jasa Keuangan No. 10/SEOJK.03/2014 Tentang Penilain Tingkat Kesehatan Bank Umum Syariah, untuk melakukan penerapan prinsip-prinsip GCG maka bank secara rutin telah melaksanakan self assesment pelaksanaan GCG. Pelaksanaan self assesment pelaksanaan GCG telah sesuai dengan SE OJK yang meliputi tiga aspek governance, yaitu governance structure, governance process dan governace outcome.
Tabel. Hasil Penilaian Self AssesmentGood Corporate Governance Bank Syariah Mandiri

\begin{tabular}{|c|c|c|}
\hline Tahun & Peringkat & Keterangan \\
\hline 2014 & 2 "Baik" & $\begin{array}{l}\text { Mencerminkan } \\
\text { Manajemen Bank telah } \\
\text { melakukan penerapan } \\
\text { Good Corporate } \\
\text { Governance yang secara } \\
\text { umum baik. Hal ini } \\
\text { tercermin dari penerapan } \\
\text { atas prinsip-prinsip Good } \\
\text { CorporateGovernance } \\
\text { yang memadai. Apabila } \\
\text { terdapat kelemahan dalam } \\
\text { penerapan prinsip Good } \\
\text { Corporate Governance } \\
\text { maka secara umum } \\
\text { kelemahan tersebut } \\
\text { kurang signifikan dan } \\
\text { dapat terselesaikan } \\
\text { dengan tindakan normal } \\
\text { oleh manajeman Bank. }\end{array}$ \\
\hline 2015 & 2 "Baik" & $\begin{array}{l}\text { Mencerminkan } \\
\text { Manajemen Bank telah } \\
\text { melakukan penerapan } \\
\text { Good Corporate } \\
\text { Governance yang secara } \\
\text { umum baik. Hal ini } \\
\text { tercermin dari penerapan } \\
\text { atas prinsip-prinsip Good } \\
\text { CorporateGovernance } \\
\text { yang memadai. Apabila } \\
\text { terdapat kelemahan dalam } \\
\text { penerapan prinsip Good } \\
\text { Corporate Governance } \\
\text { maka secara umum } \\
\text { kelemahan tersebut } \\
\text { kurang signifikan dan } \\
\text { dapat terselesaikan } \\
\text { dengan tindakan normal } \\
\text { oleh manajeman Bank. }\end{array}$ \\
\hline $\begin{array}{l}\text { Tahun } \\
2016\end{array}$ & $\begin{array}{l}1 \text { "Sangat } \\
\text { Baik" }\end{array}$ & $\begin{array}{l}\text { Mencerminkan } \\
\text { Manajemen Bank telah } \\
\text { melakukan penerapan } \\
\text { Good Corporate } \\
\text { Governance yang secara } \\
\text { umum dengan sangat } \\
\text { baik. Hal ini tercermin } \\
\text { dari penerapan atas } \\
\text { prinsip-prinsip Good } \\
\text { CorporateGovernance } \\
\text { yang memadai. Apabila } \\
\text { terdapat kelemahan dalam } \\
\text { penerapan prinsip Good } \\
\text { Corporate Governance } \\
\text { maka secara umum }\end{array}$ \\
\hline
\end{tabular}




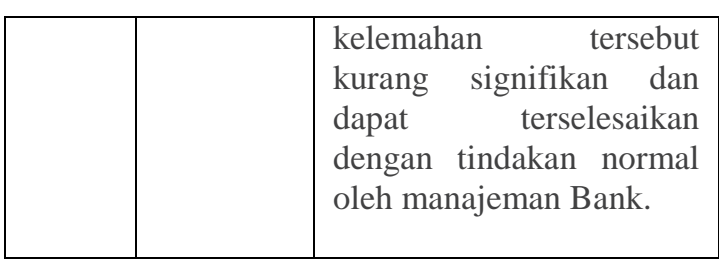

Sumber: Laporan Keuangan Tahunan Bank Syariah Mandir tahun 2016

Dari hasil diatas menunjukan bahwa Bank Syariah Mandiri telah menjalankan 11 poin penilaian yang telah ditetapkan oleh Otoritas Jasa Keuangan dengan baik, meliputi aspek penilaian terhadap struktur, proses dan hasil yang diperoleh yaitu dengan adanya pelaksanaan pembagian tugas, tanggungjawab, profesionalitas, transparansi dan kewajaran yang dilakukan oleh pihak internal maupun pihak eksternal yang berkaitan dengan operasional Bank Syariah Mandiri dibuktikan dengan pendapat predikat baik dan pengalami perbaikan kinerja dengan mendapat predikat sangat baik untuk penilaian Good Corporate Governance nya. Apabila terjadi kesalahn dalam pelaksanaan tugas, maka kesalahan tersebut dapat diselesaikan oleh manajemen bank dengan baik.

\section{c. Rentabilitas}

Penilaian Faktor Rentabilitas meliputi evaluasi terhadap rentabilitas, sumbersumber rentabilitas, kesinambungan rentabilitas, manajemen rentabilitas dan pelaksanaan fungsi sosial. Penilaian faktor Rentabilitas bank dapat menggunakan rasio diantaranya sebagai berikut:

\section{1) ROA (Return on Asset)}

Return On Asset (ROA) merupakan rasio untuk mengukur kemampuan bank menghasilkan laba dengan menggunakan asetnya. semakin rendah rasio ROA maka semakin buruk perbankan untuk menghasilkan laba melalui asetnya.

Tabel. Perhitungan Rasio ROA Bank Syariah Mandiri (Dalam Miliran Rupiah)

\begin{tabular}{|c|c|c|c|}
\hline Tahun & $\begin{array}{c}\text { Laba Sebelum } \\
\text { Pajak }\end{array}$ & $\begin{array}{c}\text { Total } \\
\text { Aset }\end{array}$ & $\begin{array}{c}\text { Rasio } \\
\text { ROA }(\%)\end{array}$ \\
\hline 2014 & 109 & 66.942 & 0,17 \\
\hline 2015 & 374 & 70.370 & 0,53 \\
\hline
\end{tabular}

\section{\begin{tabular}{l|l|l|l|}
2016 & 435 & 78.832 & 0,55 \\
\hline
\end{tabular} Sumber: Laporan Keuangan Tahunan Bank Syariah Mandir tahun 2016}

Setelah melakukan analisis antara laba sebelum pajak dengan total aset, maka selanjutnya menghitung nilai ROA BSM, ROA pada periode desember 2014 sebesar $0,17 \%$, tahun 2015 menjadi $0,53 \%$, kemudian tahun 2016 rasio ROA BSM sebesar $0,55 \%$. Dari uraian diatas BSM mendapat peringkat "kurang Sehat" dalam periode tahun 2014, BSM belum mampu menghasilkan laba melalui asetnya. Pada tahun 2015-2016 BSM menunjukan kinerja yang cukup bagus dengan kenaikan rasio ROA menjadi 0,53\% walaupun masih mendapat predikat "kurang Sehat"tetapi BSM mampu meningkatkan rasio ROA setiap tahunnya. Menunjukan kinerja yang baik.

\section{2) NOM (Net Operating Margin)}

NOM digunakan untuk mengetahui kemampuan aktiva produktif dalam menghasilkan laba. semakin kecil rasio NOM maka semakin buruk aktiva produktif dalam menghasilkan laba.

Tabel. Perhitungan Rasio NOM Bank Syariah Mandiri (Dalam Miliran Rupiah)

\begin{tabular}{|c|c|c|c|c|}
\hline Tahun & $\begin{array}{c}\text { Pend. } \\
\text { Penyaluran } \\
\text { Dana Stlh } \\
\text { Bagi Hasil }\end{array}$ & $\begin{array}{c}\text { Beban } \\
\text { Operasional }\end{array}$ & $\begin{array}{c}\text { Aset } \\
\text { Produktif }\end{array}$ & $\begin{array}{c}\text { Rasio } \\
\text { NOM } \\
(\%)\end{array}$ \\
\hline 2014 & 2.934 & 2.874 & 61.766 & 0,09 \\
\hline 2015 & 3.522 & 3.045 & 65.087 & 0,73 \\
\hline 2016 & 4.128 & 3.376 & 72.968 & 1,03 \\
\hline
\end{tabular}

Sumber: Laporan Keuangan Tahunan Bank Syariah Mandir tahun 2016

Setelah melakukan analisis terhadap pendapatan penyaluran dana setelah bagi hasil dikurangi dengan beban operasional dengan aset produktif BSM, maka selanjutnya menghitung nilai rasio NOM BSM, Net Operating Margin BSM perioe desember 2014 sebesar 0,09\%, ditahun $0,73 \%$ dan akhir periode desember 2016 sebesar $1,03 \%$. Hasil rasio NOM di atas menunjukan bahwa BSM masih dinyatakan 
"tidak Sehat" dalam mengetahui kemampuan aktiva produktifnya dalam menghasilkan laba yang akan diperoleh oleh BSM pada tahun 2014-2015 , mengalami perbaikan kinerja walaupun tidak signifikan dengan mendapat predikat "Kurang Sehat" di tahun 2016. BSM masih harus bekerja keras memperbaiki kinerja dalam penilaian Rasio ROA.

\section{d. Permodalan}

Penilaian Faktor Permodalan meliputi evaluasi terhadap kecukupan modal dan kecukupan pengelolaan permodalan. Penilaian menggunakan rasioCapital Adequacy Ratio (CAR) merupakan rasio yang digunakan untuk menghitung tingkat kesehatan modal bank. CAR adalah rasio yang memperlihatkan seberapa besar seluruh aktiva bank yang mengandung risiko (kredit, penyertaan, surat berharga, tagihan pada bank lain).

\section{Tabel. Perhitungan Rasio CAR Bank Syariah Mandiri (Dalam Miliaran Rupiah)}

\begin{tabular}{|c|c|c|c|}
\hline Tahun & Modal & ATMR & $\begin{array}{c}\text { Rasio CAR } \\
(\%)\end{array}$ \\
\hline 2014 & 4.617 & 65.192 & 14,12 \\
\hline 2015 & 5.614 & 72.139 & 12,85 \\
\hline 2016 & 6.392 & 89.522 & 14,01 \\
\hline
\end{tabular}

Sumber: Laporan Keuangan Tahunan Bank Syariah Mandir tahun 2016

Setelah melakukan analisis modal terhadap Aktiva Tertimbang Menurut Risiko (ATMR), maka selanjutnya menghitung nilai CAR BSM. CAR pada periode desember 2014 sebesar 14,12\%, tahun 2015 mengalami penurunan dalam rasio CAR menjadi 12,85\%, dan tahun 2016 nilai rasio CAR menjadi $14,01 \%$. Hal ini menunjukan CAR BSM setiap tahunnya mengalami fluktuasi Rasio CAR tapi tetap dalam keadaan stabil, menunjukan bahwa rasio CAR lebih dari 12\% dikatakan sangat Sehat karena melebihi rasio CAR yang ditetapkan berdasarkan Kewajiban Penyediaan modal minimum Bank Umum Syariah berdasarkan prinsip syariah.

\section{Analisis Rasio Keuangan Bank Muamalat Indonesia \\ a. Profil Risiko}

Penilaian faktor profil risiko merupakan penilaian terhadap risiko inhern dan kualitas penerapan Manajemen Risiko dalam aktivitas operasional bank. Penilaian untuk profil risiko bank terbagi menjadi beberapa alternatif rasio diantara yang penulis pilih adalah NPF (Non Performing Financing) dan FDR (Financing To Deposit Rasio).

\section{1) NPF (Non Performing Financing)}

merupakan rasio untuk mengukur tingkat pembiayaan bermasalah terhadap total pembiayaan yang dihadapi oleh Bank Syariah. Semakin tinggi rasio NPF menunjukan kualitas pembiayaan bank syariah yang semakin buruk terhadap pembiayaan yang dihadapi bank.

Tabel. Perhitungan Rasio NFP Bank Muamalat Indonesia (Dalam Miliaran Rupiah)

\begin{tabular}{|c|c|c|c|}
\hline Tahun & $\begin{array}{c}\text { Total } \\
\text { Pembiayaan }\end{array}$ & $\begin{array}{c}\text { Pembiayaan } \\
\text { Bermasalah }\end{array}$ & $\begin{array}{c}\text { Rasio } \\
\text { NPF (\%) }\end{array}$ \\
\hline 2014 & 42.865 & 2.074 & 4,85 \\
\hline 2015 & 40.706 & 1.709 & 4,2 \\
\hline 2016 & 40,01 & 560 & 1,4 \\
\hline
\end{tabular}

Setelah melakukan analisis antara total pembiayaan dengan pembiayaan bermasalah, maka selanjutnya melakukan perhitungan nilai rasio NPF (Non Performing Financing), NPF BMI per 31 desember 2014 mendapat rasio sebesar $4,85 \%$, mengalami penurunan menjadi $4,20 \%$ diperiode desember 2015 , pada desember 2016 rasio NPF BMI mengalami penurunan yang signifikan menjadi $1,40 \%$. Dari uraian diatas menunjukan bahwa dengan menurunnya rassio NPF dari 4,85\%dengan predikat untuk penilaian NPF dengan Kriteria "Sehat" menjadi $1,40 \%$ dengan mendapat kriteria penilaian "Sangat Sehat" menunjukan bahwa BMI mampu mengelola pembiayaan bermasalah yang dihadapi dengan sangat baik. 
FDR (Financing to Deposite Ratio )

FDR merupakan rasio yang digunakan untuk mengukur tingkat likuiditas suatu bank, dengan cara membandingkan antara pembiayaan yang disalurkan dengan dana yang dihimpun dari masyarakat sehingga dapat diketahui kemampuan bank dalam membayar kewajiban jangka pendeknya. Semakin tinggi rasionya maka semakin rendah kemampuan likuiditas bank tersebut.

Tabel. Perhitungan Rasio FDR Bank Muamalat Indonesia (Dalam Miliaran Rupiah)

\begin{tabular}{|c|c|c|c|}
\hline Tahun & $\begin{array}{c}\text { Total } \\
\text { Pembiayaan }\end{array}$ & $\begin{array}{c}\text { Total Dana } \\
\text { Pihak Ketiga }\end{array}$ & $\begin{array}{c}\text { Rasio } \\
\text { FDR (\%) }\end{array}$ \\
\hline 2014 & 42.865 & 51.206 & 83,71 \\
\hline 2015 & 40.706 & 45.078 & 90,3 \\
\hline 2016 & 40.010 & 41.920 & 95,44 \\
\hline
\end{tabular}
Sumber: Laporan Keuangan Tahunan Bank
Muamalat Indonesia tahun 2016

Setelah melakukan analisis antara pembiayaan dengan jumlah dana pihak ketiga, maka selanjutnya menghitung rasio FDR (Financing to Depisite Ratio) BMI, FDR pada akhir desember 2014 sebesar 83,71\%, ditahun 2015 mengalami kenaikan rasio FDR menjadi 90,30\%, dan kembali naik di periode 2016 menjadi 95,44\%. Dari uraian diatas dapat di simpulkan bahwa BMI dalam setiap tahunnya mengalami kenaikan rasio FDR menandakan bahwa kinerja BMI dalam membayar kewajiban jangka pedeknya atau kemampuan likuidasi BMI semakin rendah, BMI hanya mendapat kriteria penilaian dengan predikat "Cukup Sehat" untuk rasio FDR.

\section{b. Good Corporate Governance}

Sebagai wujud komitmen Bank Muamalat Indonesia terhadap Surat Edaran Otoritas Jasa Keuangan No. 10/SEOJK.03/2014 Tentang Penilain Tingkat Kesehatan Bank Umum Syariah, untuk melakukan penerapan prinsip-prinsip GCG maka bank secara rutin telah melaksanakan self assesment pelaksanaan GCG. Pelaksanaan self assesmentpelaksanaan GCG telah sesuai dengan SE OJK yang meliputi tiga aspek governance, yaitu governance structure, governance process dan governace outcome.

Tabel. Hasil PenilaianSelf Assesment Good Corporate Governance Bank Muamalat Indonesia

\begin{tabular}{|c|c|c|}
\hline Tahun & Peringkat & Keterangan \\
\hline 2014 & $\begin{array}{l}3 \text { "Cukup } \\
\text { Baik" }\end{array}$ & $\begin{array}{l}\text { yang mencerminkan } \\
\text { Manajemen Bank telah } \\
\text { melakukan penerapan } \\
\text { GoodCorporate } \\
\text { Governance yang secara } \\
\text { umum Cukup Baik.Atas } \\
\text { hal tersebut BMI akan } \\
\text { terus berupaya agar } \\
\text { GCGBMI kedepannya } \\
\text { semakin baik dengan } \\
\text { melakukanupaya-upaya } \\
\text { atau langkah-langkah } \\
\text { yang optimal dan } \\
\text { maksimaldi semua aspek } \\
\text { Governance dari } \\
\text { Governance } \\
\text { Structure,Governance } \\
\text { Process, Governance } \\
\text { Outcome guna } \\
\text { memaksimalkan } \\
\text { kemanfaatan } \\
\text { shareholder bagi } \\
\text { stakeholder. }\end{array}$ \\
\hline 2015 & $\begin{array}{l}3 \text { "Cukup } \\
\text { Baik" }\end{array}$ & $\begin{array}{l}\text { Mencerminkan } \\
\text { Manajemen Bank telah } \\
\text { melakukan penerapan } \\
\text { Good Corporate } \\
\text { Governance yang secara } \\
\text { umum cukup baik. Hal } \\
\text { ini tercermin dari } \\
\text { penerapan atas prinsip- } \\
\text { prinsip Good } \\
\text { CorporateGovernance } \\
\text { yang cukup memadai. } \\
\text { Apabila terdapat } \\
\text { kelemahan dalam } \\
\text { penerapan prinsip Good } \\
\text { Corporate Governance } \\
\text { maka secara umum } \\
\text { kelemahan tersebut } \\
\text { cukup signifikan dan } \\
\text { memerlukan perhatian } \\
\text { yang cukup dari } \\
\text { manajemen Bank. }\end{array}$ \\
\hline 2016 & 2 "baik" & $\begin{array}{l}\text { Mencerminkan } \\
\text { Manajemen Bank telah } \\
\text { melakukan penerapan } \\
\text { Good Corporate } \\
\text { Governance yang secara } \\
\text { umum baik. Hal ini } \\
\text { tercermin dari penerapan }\end{array}$ \\
\hline
\end{tabular}




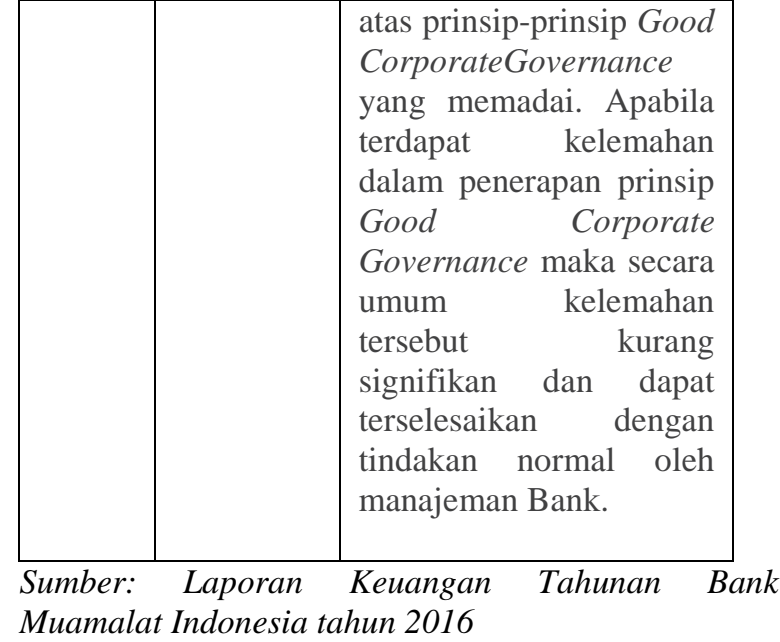

Bank Muamalat Indonesia telah menunjukan Komitmennya dalam menjalankan 11 poin penilaian yang telah ditetapkan oleh Otoritas Jasa Keuangan dengan cukup baik, Bank Muamalat Indonesia selalu berupaya agar GCG BMI akan semakin Baik kedepannya dengan melakukan upaya dari aspek governance structure, governance proses dan governance outcome, untuk penilaian pelaksanaan pembagian tugas, tanggungjawab, profesionalitas, transparansi dan kewajaran yang dilakukan oleh pihak internal maupun pihak eksternal yang berkaitan dengan operasional Bank Muamalat indoeseia dengan pendapat predikat penilaian cukup baik dan pengalami perbaikan kinerja dengan mendapat predikat baik untuk penilaian Good Corporate Governance nya. Apabila terjadi kesalahn dalam pelaksanaan tugas, maka kesalahan tersebut dapat diselesaikan oleh manajemen bank dengan baik.

\section{c. Rentabilitas}

Penilaian Faktor Rentabilitas meliputi evaluasi terhadap rentabilitas, sumbersumber rentabilitas, kesinambungan rentabilitas, manajemen rentabilitas dan pelaksanaan fungsi sosial. Penilaian faktor Rentabilitas bank dapat menggunakan rasio diantaranya sebagai berikut:

\section{1) ROA (Return on Asset)}

Return On Asset (ROA) merupakan rasio untuk mengukur kemampuan bank menghasilkan laba dengan menggunakan asetnya. semakin rendah rasio ROA maka semakin buruk perbankan untuk menghasilkan laba melalui asetnya.

Tabel. Perhitungan Rasio ROA Bank Muamalat Indonesia (Dalam Miliaran Rupiah)

\begin{tabular}{|c|c|c|c|}
\hline Tahun & $\begin{array}{c}\text { Laba Sebelum } \\
\text { Pajak }\end{array}$ & $\begin{array}{c}\text { Total } \\
\text { Aset }\end{array}$ & $\begin{array}{c}\text { Rasio } \\
\text { ROA (\%) }\end{array}$ \\
\hline 2014 & 99 & 62.410 & 0,16 \\
\hline 2015 & 109 & 57.141 & 0,2 \\
\hline 2016 & 116 & 55.786 & 0,21 \\
\hline Sumber: Laporan Keuangan Tahunan Bank \\
Muamalat Indonesia tahun 2016
\end{tabular}

Setelah melakukan analisis antara laba sebelum pajak dengan total aset, maka selanjutnya menghitung rasio ROA (Return On Asset), ROA BMI periode desember 2014 sebesar $0,16 \%$, ditahun 2015 sebesar 0,20\% dan di akhir periode desember 2016 rasio ROA BMI sebesar 0,21\%. Dari perolehan hasil ROA diatas dapat di artikan bahwa rasio ROA yang dihasilkan dari laba sebelum pajak dengan total aset ditahun 2014 hingga 2016 mandapat rasio > 0,5\% menunjukan bahwa BMI belum mampu menghasilkan laba melalui aset yang dimiliki. BMI hanya mendapat kriteria penilaian rasio dengan predikat "Kurang Sehat" pada periode 2014 hingga 2016.

2) NOM (Net Operating Margin)

NOM digunakan untuk mengetahui kemampuan aktiva produktif dalam menghasilkan laba. semakin kecil rasio NOM maka semakin buruk aktiva produktif dalam menghasilkan laba.

Tabel. Perhitungan Rasio NOM Bank Muamalat Indonesia (Dalam Miliran Rupiah)

\begin{tabular}{|c|c|c|c|c|}
\hline Tahun & $\begin{array}{c}\text { Pend. } \\
\text { Penyaluran } \\
\text { Dana stlh } \\
\text { Bagi Hasil }\end{array}$ & $\begin{array}{c}\text { Beban } \\
\text { Operasional }\end{array}$ & $\begin{array}{c}\text { Aset } \\
\text { Produktif } \\
\end{array}$ & $\begin{array}{c}\text { Rasio } \\
\operatorname{NOM}(\%)\end{array}$ \\
\hline 2014 & 1.863 & 1.853 & 49.864 & 0,02 \\
\hline 2015 & 2.095 & 2.011 & 47.147 & 0,18 \\
\hline 2016 & 1.499 & 1.709 & 45.872 & $-0,46$ \\
\hline
\end{tabular}

Setelah malakukan analisis antara Pendapatan penyaluran dana setelah bagi 
hasil yang dikurangi dengan beban operasional dengan aktiva produktif, maka selanjutnya menghitung rasio NOM (Net Operating Margin), NOM BMI pada tahun 2014 sebesar $0,02 \%$, tahun 2015 0,18\%, dan ditahun 2016 sebesar -0,46\%. Dengan hasl perolehan rasio NOM diatas, BMI belum mampu dengan aktiva produktif yang mereka miliki untuk menghasilkan laba, dikarenakan rasio NOM yang $>1 \%$ menunjukan bahwa kinerja BMI dalam menghasilkan laba melalui aktiva produktif hanya mendapat predikat "Tidak Sehat" dalam menghasilkan laba yang dinilai dengan rasio NOM.

\section{d. Permodalan}

Peniaian Faktor Permodalan meliputi evaluasi terhadap kecukupan modal dan kecukupan pengelolaan permodalan. Penilaian menggunakan rasioCapital Adequacy Ratio (CAR) merupakan rasio yang digunakan untuk menghitung tingkat kesehatan modal bank. CAR adalah rasio yang memperlihatkan seberapa besar seluruh aktiva bank yang mengandung risiko (kredit, penyertaan, surat berharga, tagihan pada bank lain)

\section{Tabel. Perhitungan Rasio CAR Bank} Muamalat Indonesia (Dalam Miliaran Rupiah)

\begin{tabular}{|c|c|c|c|}
\hline Tahun & Modal & ATMR & Rasio CAR (\%) \\
\hline 2014 & 3.896 & 54.193 & 13,91 \\
\hline 2015 & 3.519 & 42.228 & 12 \\
\hline 2016 & 3.619 & 46.107 & 12,74 \\
\hline Sumber: & \multicolumn{2}{|c|}{ Laporan Keuangan Tahunan Bank }
\end{tabular}

Muamalat Indonesia tahun 2016

Setelah melakukan analisis data antara modal dengan ATMR, maka selanjutnya melakukan analisis rasio CAR, CAR BMI tahun 2014 13,91\%, ditahun 2015 12,00\% dan tahun 2016 12,74\%. Dari hasil rasio CAR tersebut BMI sudah memenuhi kewajiban penyediaan modal minimum bank umum syariah berdasarkan prinsip syariah, di buktikan BMI mendapat penilaian rasio CAR $>12 \%$ walaupun sempat mengalami penurunan tetapi masih dalam kriteria penilaian dengan predikat CAR "Sangat Sehat" untuk hasil rasio CAR BMI.

\section{Uji hipotesis}

Hasil uji beda dengan menggunakan indepentdent sample t-test rasio keuangan Bank Syariah Mandiri dan Bank Muamalat Indonesia dengan menggunkan metode Riskbased Bank Rating dapat ditampilkan dalam tabel berikut :

\section{Profil Risiko}

\section{Tabel. Hasil Uji Perbandingan Kesehatan Bank Syariah Mandiri dan Bank Muamalat Indonesia}

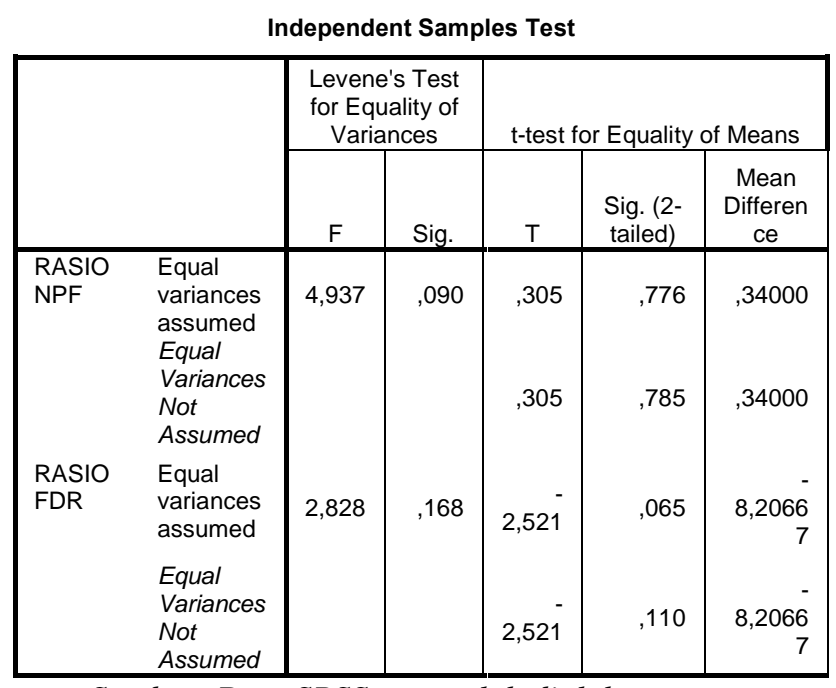

Sumber: Data SPSS yang telah diolah

Tabel di atas menunjukan bahwa $\mathrm{F}$ hitung untuk rasio NPF dengan Equal Variances Assumed sebesar 4,937, dengan nilai sig. 0,090. Dari data diatas menujukan bahwa $\mathrm{F}$ hitung dengan nilai sig. > 0,05. Maka di katakan bahwa tidak terdapat perbedaan varian pada data perbandingan kesehatan bank Bank Syariah Mandiri dan Bank Muamalat Indonesia untuk rasio NPF

Bila kedua varian sama, maka sebaiknya menggunakan Equal Variances Assumed untuk t hitung. Equal Variances Assumed nilai t hitung sebesar 0,305 dengan nilai sig. 0,776 , dikatakan nilai $t$ hitung dengan sig > t tabel $(0,776>0,05)$ maka dapat dikatakan bahwa kesehatan keuangan 
Bank Syariah Mandiri dan Bank Muamalat Indonesia tidak terdapat perbedaan yang signifikan untuk rasio NPF.

Penilaian faktor Profil Risiko merupakan penilaian terhadap risiko inhern dan kualitas penerapan manajemen risiko dalam aktivitas operasional bank. Risiko inhern merupakan penilaian atas risiko yang melekat pada kegiatan bisnis bank, baik yang dapat di kuantifikasikan maupun tidak, yang berpotensi mempengaruhi posisi keuangan salah satunnya adalah risiko kredit. Risiko kredit adalah risiko akibat kegagalan nasabah atau pihak lain dalam memenuhi kewajiban kepada bank sesuai dengan perjanjian yang disepakati.

Dengan tidak terdapat perbedaan yang signifikan antara kesehatan Bank Syariah Mandiri dan Bank Muamalat Indonesia dalam perbandingan rasio NPF, dimana rasio NPF digunakan untuk mengukur tingkat pembiayaan bermasalah yang dihadapi oleh bank syariah dan rasio NPF yang diperoleh kedua bank tersebut dibawah angka 5\% yang merupakan batas maksimal nilai NPF bank syariah menunjukan bahwa terdapat prinsip kehati-hatian yang dilakukan bank syariah pada saat melakukan kegiatan pendanaan dan kedua bank tersebut dapat menangani risiko kredit yang dihadapi dengan sangat baik.

Nilai $\mathrm{F}$ hitung untuk rasio FDR dengan Equal Variances Assumed sebesar 2,828, dengan nilai sig. 0,168. Dari data diatas menunjukan bahwa $\mathrm{F}$ hitung memiliki nilai sig. > 0,05 maka dikatakan bahwa untuk rasio FDR antara Bank Syariah Mandiri dan Bank Muamalat Indonesia tidak terdapat perbedaan varian untuk perbandingan kesehatannya.

Bila kedua varian sama, maka sebaiknya menggunakan Equal Variances Assumed untuk t hitung, t hitung untuk rasio FDR sebesar -2,521 dengan nilai sig. 0,065. Nilai sig. $t$ hitung $>\mathrm{t}$ tabel $(0,065>0,05)$. Maka dinyatakan bahwa kesehatan keuangan Bank Syariah Mandiri dan Bank Muamalat
Indonesia tidak terdapat perbedaan yang signifikan untuk rasio FDR.

Risiko likuiditas adalah risiko akibat ketidak mampuan bank untuk memenuhi kewajiban yang jatuh tempo dari sumber pendanaan arus kas atau aset likuid berkualitas tinggi yang dapat diagunkan tanpa mengganggu aktivitas dan kondisi keuangan bank yang dinilai dengan rasio FDR, rasio FDR digunakan untuk mengukur tingkat likuiditas suatu bank, dengan cara membandingkan antara pembiayaan yang disalurkan dengan dana yang dihimpun dari masyarakat sehingga dapat diketahui kemampuan bank dalam membayar kewajiban jangka pendeknya.

Tidak terdapat perbedaan yang signifikan pada rasio FDR pada Bank Syariah Mandiri dan Bank Mumalat Indonesia, menunjukan bahwa kedua bank mampu memenuhi kewajiban jangka pendeknya dengan baik, walaupun terdapat perbedaan jika BSM setiap tahunnya rasio FDR yang diperoleh semakin kecil manunjukan kinerja bank yang semakin membaik, sedangkan BMI setiap tahunnya rasio FDR yang diperoleh semakin tinggi menandakan kinerja BMI mengalami penurunan kinerja. Walaupun terdapat perbedaan akan tetapi perbedaan tersebut tidaklah signifikan.

\section{Good Corporate Governance}

\section{Tabel. Hasil Uji Hasil Uji Perbandingan Kesehatan Bank Syariah Mandiri dan Bank Muamalat Indonesia}

\begin{tabular}{|c|c|c|c|c|c|c|}
\hline \multicolumn{7}{|c|}{ Independent Samples Test } \\
\hline & & \multicolumn{2}{|c|}{$\begin{array}{c}\text { Levene's Test } \\
\text { for Equality of } \\
\text { Variances }\end{array}$} & \multicolumn{3}{|c|}{ t-test for Equality of Means } \\
\hline & & $\mathrm{F}$ & Sig. & $\mathrm{T}$ & $\begin{array}{l}\text { Sig. (2- } \\
\text { tailed) }\end{array}$ & $\begin{array}{c}\text { Mean } \\
\text { Difference }\end{array}$ \\
\hline GCG & $\begin{array}{l}\text { Equal } \\
\text { variances } \\
\text { assumed } \\
\text { Equal } \\
\text { Variances } \\
\text { Not } \\
\text { Assumed }\end{array}$ & $\begin{array}{r}0,00 \\
0\end{array}$ & 1,000 & $\begin{array}{r}- \\
2,12 \\
1 \\
\\
- \\
2,12 \\
1\end{array}$ &, 101 & $-1,00000$ \\
\hline
\end{tabular}

Sumber: Data SPSS yang telah diolah 
Nilai $\mathrm{F}$ hitung untuk GCG dengan Equal Variances Assumed sebesar 0,000 dengan nilai sig. 1,000. Dari data diatas menunjukan bahwa $\mathrm{F}$ hitung memiliki nilai sig. > 0,05 maka dikatakan bahwa untuk rasio GCG antara Bank Syariah Mandiri dan Bank Muamalat Indonesia tidak terdapat perbedaan varian untuk perbandingan kesehatannya yang ditinjau dengan GCG.

Apabila kedua varian sama, maka untuk membandingkan dua bank sebaiknya dengan menggunakan dasar Equal Variances Assumed untuk $\mathrm{t}$ hitungnya. Diketahui $\mathrm{t}$ hitung dengan nilai $-2,121$, dengan nilai sig. 0,101 , menunjukan bahwa sig. $\mathrm{t}$ hitung $>\mathrm{t}$ tabel $(0,101>0,05)$, maka di katakan bahwa kesehatan keuangan Bank Syariah Mandiri dan Bank Muamalat Indonesia tidak terdapat perbedaan yang signifikan untuk penilaian GCG.

Penilaian faktor Good Corporate Governancebagi bank umum syariah merupakan penilaian terhadap kualitas manajemen bank atas pelaksanaan lima prinsip GCG (transaparansi, akuntabilitas, pertanggungjawaban, profesional dan kewajaran), pelaksanaan GCG sesuai dengan Surat Edaran Otoritas Jasa Keuangan yang meliputi 3 aspek kecukupan tata kelola atas struktur, proses dan hasil penerapan GCG dan informasi lain yang terkait dengan tata kelola yang digunakan pada data dan informasi yang relevan.

Hasil perbandingan diatas menunjukan tidak terdapat perbedaan yang signifikan pada penilaian faktor GCG. Kedua bank tersebut telah melaksanakan penerapan GCG sesuai dengan peraturan yang berlaku dan manajemen bank telah melaksanakan GCG dengan baik hal ini tercermin dari penerapan atas prinsip-prinsip GCG yang memadai karena jika terdapat kelemahan dalam penerapan GCG tersebut kurang signifikan dan dapat terselesaiakan dengan tindakan normal oleh manajemen bank, kedua bank juga membuktikan dengan penilaian untuk faktor GCG setiap tahunnya mengalami perbaikan kinerja yang bagus.

\section{Rentabilitas \\ Tabel. Hasil Hasil Uji Perbandingan \\ Kesehatan \\ Bank Syariah Mandiri dan Bank \\ Muamalat Indonesia}

\begin{tabular}{|c|c|c|c|c|c|c|}
\hline \multicolumn{7}{|c|}{ Independent Samples Test } \\
\hline & & \multicolumn{2}{|c|}{$\begin{array}{l}\text { Levene's Test } \\
\text { for Equality of } \\
\text { Variances }\end{array}$} & \multicolumn{3}{|c|}{ t-test for Equality of Means } \\
\hline & & $\mathrm{F}$ & Sig. & $\mathrm{T}$ & $\begin{array}{c}\text { Sig. } \\
\text { (2- } \\
\text { taile } \\
\text { d) }\end{array}$ & $\begin{array}{l}\text { Mean } \\
\text { Differen } \\
\text { ce }\end{array}$ \\
\hline \multirow[t]{2}{*}{$\mathrm{ROA}$} & $\begin{array}{l}\text { Equal } \\
\text { variances } \\
\text { assumed }\end{array}$ & 11,876 & ,026 & 1,822 & ,143 & ,22667 \\
\hline & $\begin{array}{l}\text { Equal } \\
\text { variances not } \\
\text { assumed }\end{array}$ & & & 1,822 & ,206 & ,22667 \\
\hline \multirow[t]{2}{*}{ NOM } & $\begin{array}{l}\text { Equal } \\
\text { variances } \\
\text { assumed }\end{array}$ & ,493 &, 521 & 2,085 & ,105 & ,70333 \\
\hline & $\begin{array}{l}\text { Equal } \\
\text { variances not } \\
\text { assumed }\end{array}$ & & & 2,085 & ,114 & ,70333 \\
\hline
\end{tabular}

Sumber: Data SPSS yang telah diolah

Dari hasil diatas terlihat bahwa $\mathrm{F}$ hitung untuk rasio ROA dengan Equal Variances Assumed sebesar 11,876, dengan nilai sig. Sebesar 0,026. F hitung dengan nilai Sig. < 0,05. Maka di katakan bahwa terdapat perbedaan varian pada data perbandingan kesehatan bank Bank Syariah Mandiri dan Bank Muamalat Indonesiaa untuk rasio ROA.

Bila kedua varian berbeda, maka untuk membandingkan kedua bank sebaiknya dengan menggunakan Equal Variances Not Assumed untuk t hitung nya. Diketahui nilai t hitung sebesar 1,822, dengan nilai sig. Sebesar 0,206, menunjukan bahwa nilai sig. $\mathrm{t}$ hitung > $\mathrm{t}$ tabel $(0,206>0,05)$. Maka dapat dinyatakan bahwa kesehatan keuangan Bank Syariah Mandiri dan Bank Muamalat Indonesia tidak terdapat perbedaan yang signifikan untuk rasio ROA.

Penilaian faktor Rentabilitas meliputi evaluasi terhadap kinerja rentabilitas, sumber-sumber rentabilitas, kesinambungan rentabilitas dan pelakanaan fungsi sosial bank syariah, yang salah saatu penilaian 
untuk faktor rentabilitas analaah analisis rasio ROA, analisis rasio ROA merupakan rasio untuk mengukur kemampuan bank syariah dalam menghasilkan laba atau keuntungan menggunakan asetnya.

Dalam hasil diatas menandakan tidak terdapat perbedaan yang signifikan untuk rasio ROA, akan tetapi Bank Syariah Mandiri jauh lebih baik kemampuan manajemen bank dalam menghasil laba melaui asetnya dimana rasio ROA BSM setiap tahunnya selalu mengalami kenaikan dan bisa mencapai $0,5 \%$ menunjukan bahwa kinerja manajemen BSM setiap tahun berhasil memperbaiki kinerjanya, sedangkan BMI belum mencapai $0,5 \%$ tetapi setiap tahun rasio ROA yang diperoleh mengalami keniakan walau belum menunjukan kenaikan yang signifikan. Walaupun terdapat perbedaan akan tetapi belum menunjukkan perbedaan yang signifikan antara rasio yang diperoleh oleh BSM dan BMI.

Nilai $F$ hitung untuk rasio NOM dengan Equal Variances Assumed sebesar 0,493 , dengan nilai sig. 0,521. F hitung dengan nilai sig. > 0,05. Maka di katakan bahwa tidak terdapat perbedaan varian pada data perbandingan kesehatan bank Bank Syariah Mandiri dan Bank Muamalat Indonesiaa untuk rasio NOM.

Apabila kedua varian sama, maka untuk membandingkan dua bank sebaiknya dengan menggunkan dasar Equal Variances Assumed untuk $\mathrm{t}$ hitungnya. Diketahui $\mathrm{t}$ hitung dengan nilai 2,085, dengan nilai sig. 0,703 , menunjukan bahwa nilai sig. t hitung $<\mathrm{t}$ tabel $(0,703<0,05)$, maka di katakan bahwa kesehatan keuangan Bank Syariah Mandiri dan Bank Muamalat Indonesia tidak terdapat perbedaan yang signifikan untuk rasio NOM.

Rasio NOM digunakan untuk mengetahui kemampuan aktiva produktif dalam menghasilkan laba dalam hasil diatas menunjukan tidak terdapat perbedaan yang signifikan dalam perbandingan rasio NOM untuk Bank Syariah Mandiri dan Bank
Muamalat Indonesia, walaupun menunjukan hasil yang tidak signifikan akan tetapi kinerja Bank Syariah Mandiri lebih baik dibanding Bank Muamalat Indonesia dikarenakan, pendapatan penyaluran dana yang diperoleh oleh BSM setiap tahunnya mengalami kenaikan yang cukup bagus, menandakan bahwa namajemen Bank Syariah Melakukan perbaikan kinerja yang dilakukan untuk mencapai hasil yang lebih baik lagi. sedangkan BMI sempat mengalami kenaikan tetapi kembali mengalami penurunan, menandakan kurangnya kemampuan manajemen bank nya dalam menghasilkan laba melalui aktiva produktif yang dimilikinya. Dan hasil diatas menunjukan kinerja BSM lebih baik dibandingkan dengan BMI, walaupun belum menunjukan perbedaan yang signifikan.

\section{Permodalan}

Tabel. Hasil Hasil Uji Perbandingan

Kesehatan Bank Syariah Mandiri dan Bank Muamalat Indonesia

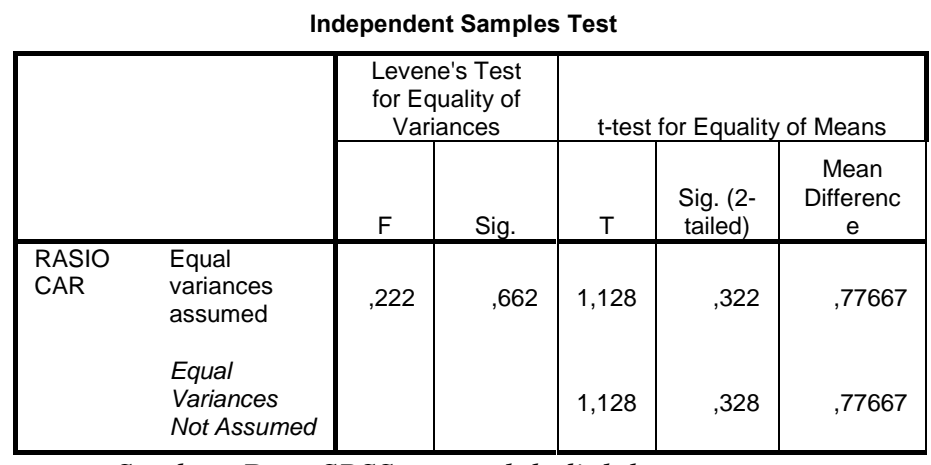

Sumber: Data SPSS yang telah diolah

Nilai $\mathrm{F}$ hitung untuk rasio CAR dengan Equal Variances Assumed sebesar 0,222, dengan nilai sig. 0,662. F hitung $>0,05$. Maka di katakan bahwa tidak terdapat perbedaan varian pada data perbandingan kesehatan bank Bank Syariah Mandiri dan Bank Muamalat Indonesiaa untuk rasio CAR.

Apabila kedua varian sama, maka untuk membandingkan dua bank sebaiknya dengan mengunakan Equal Variances Assumed untuk t hitungnya. Nilai $\mathrm{t}$ hitung 1,128 , dengan nilai sig. 0,322 . Menunjukan 
bahwanilai sig. $\mathrm{t}$ hitung $>\mathrm{t}$ tabel $(0,322>$ 0,05), maka dinyatakan bahwa kesehatan keuangan Bank Syariah mandiri dan Bank Muamalat Indonesia tidak terdapat perbedaan yang signifikan untuk rasio CAR.

Penilaian faktor permodalan meliputi evaluasi terhadap kecukupan modal dan kecukupan pengelolaan permodalan, dalam melakukan perhitungan permodalan bank umum syariah mangacu pada ketentuan yang berlaku mengenai kewajiban penyediaan modal minimum bagi bank umum syariah. Bank harus menyediakan kewajiban penyediaan modal minimum (KPMM) $8 \%$ agar kinerja keuangan bank dinilai baik.

Kedua bank tersebut telah memenuhi kewajiban minimum penyediaan modal dengan memperoleh rasio CAR lebih dari 8\% setiap tahunnya. Dan penilaian kedua bank tersebut tidak terdapat perbedaan yang signifikan menandakan bahwa BSM dan BMI dapat memperlihatkan seberapa besar aktiva bank yang mengandung risiko dengan penanganan yang baik. Karena dalam melakukan penilaian kecukupan modal, Bank Syariah juga harus mengaitkan kecukupan modal dengan profil risiko. Semakin tinggi risiko, semakin besar pula modal yang harus disediakan untuk mengantisipasi risiko tersebut.

\section{Penutup}

Berdasarkan pengolahan data dan hasil analisis pengujian data secara deskriptif dan statistik, dapat diperoleh beberapa kesimpulan sebagai berikut:

Penilaian kesehatan dengan penilaian Profil Risiko pada BSM pada periode 2014 hingga 2016 mendapat predikat penilaian SEHAT untuk rasio NPF, dan untuk rasio FDR periode tahun 2014 hingga 2016 mendapat predikat SEHAT, untuk GCG BSM tahun 2014 dan 2015 menadapat predikat BAIK untuk penilaian GCG TAHUN 2016 BSM mendapat peringkat 1 yaitu SANGAT BAIK untuk penilain GCG, penilaian kesehatan dengan faktor Rentabilitas BSM pada periode 2014 hingga
2016 masuk dalam kategori KURANG SEHAT untuk rasio ROA, dan untuk rasio NOM BSM masuk dalam kategori TIDAK SEHAT, pada tahun 2014-2015, untuk 2016 mendapat predikat CUKUP SEHAT, penilaian dengan faktor Permodalan BSM mampu mendapat predikat SANGAT SEHAT untuk rasio CAR pada periode 2014 hingga 2016. Penilaian kesehatan Bank Muamalat Indonesia ditinjau dari Profil Risiko pada periode 2014 dan 2015 BMI mendapat penilaian SEHAT untuk rasio NPF dan periode 2016 BMI mendapat predikat SANGAT SEHAT untuk rasio NPF nya, periode 2014 hingga 2016 BMI hanya mendapat kategori CUKUP SEHAT untuk rasio FDR. Penilaian kesehatan bank ditinjau dengan Good Corporate Governance BMI pada periode 2014 dan 2015 mendapat peringkat ke 3 yaitu CUKUP BAIK untuk pengelolaan GCG, pada periode 2016 BMI mendapat peringkat 2 dengan predikat BAIK untuk GCG. Penilaian ditinjau dengan faktor Rentabilitas BMI pada tahun 2014 hingga 2016 mendapat predikat KURANG SEHAT untuk rasio ROA, dan rasio NOM BMI pada periode 2014 sampai 2016 menadapat predikat TIDAK SEHAT. Penilaian faktor Permodalan BMI mendapat predikat SANGAT SEHAT untuk rasio CAR pada periode 2014 hingga 2016.

Tidak terdapat perbedaan yang signifikan untuk perbandingan kesehatan keuangan BSM dan BMI yang ditinjau dengan menggunakan pendekatan Risk-based Bank Rating dengan menggunakan independent sample t-test

\section{DAFTAR PUSTAKA}

Adiwarman A, Karim. Bank Islam: Analisiis Fiqh dan Keuangan, Jakarta: PT.Rajagrafindo Persada, 2010.

Ali, Masyhud.Manajemen Risiko. Jakarta: PT. RajaGrafindo Persada, 2006

Bungin, Burhan. Metodologi penelitian Kuantitatif, jakarta: kencana Prenada media Grup, 2005. 
Darmawan, Deni. Metode Penelitian Kuantitatif, Bandung: PT. Remaja Rosdakarya, 2013.

Dharmapurmata Susanti, Sandhy. Analisis Tingkat Kesehatan bank Dengan Menggunakan MetodeRisk-Based Bank Rating. Skripsi S1 fakultas Ekonomi Universitas Negeri Yogyakarta, Yogyakarta, 2014.

Duantika, Defri. Analisa Perbandingan Kinerja Bank Syariah Berdasarkan RGEC danIslamicity Performance Index (Studi Bank Muamalat Indonesia dan Bank Mandiri periode 2010-1014). Skripsi S1 Fakultas Syariah dan Hukum, Universitas Islam Negeri Syarif Hidayatullah, Jakarta, 2014.

Hafidhuddin, Dkk. Manajemen Syariah Dalam Praktik. Jakarta: Gema Insani Press.

Hari, Sudarsono. Bank dan Lembaga Keuanagan Syariah. Yogyakarta: EKONOSIA, 2006.

Helfert. A, Erich. Teknik Analisis Keuangan petunjuk Praktis Untuk Mengelola dan Mengukur Kinerja Perusahaaan. Jakarta: Penerbit Erlangga, 1997.

Kasmir. Bank dan Lembaga Keuangan Lainnya, Edisi Keenam. Jakarta: PT.Raja Grafindo Persada, 2002.

Kasmir. Bank dan Lembaga Keuangan Lainnya. Jakarta: PT. RajaGrafindo Persada, 2013.

Komang Mahenda Pramana, Luh gede sri artini. Analisis tingkat kesehatan bank (pendekatan RGEC) pada PT. Bank Danamon Indonesia TBK, EJurnal Manajemen Unud, 2014, V01.5, No.6, 2014.

Mamu, Mariani, Frendy.A.Opelleng, Dantje kelles. Analisis Tingkat Kesehatan Bank BNI Syariah Dengan menggunakan Metode RGEC periode 2012-2014. Jurnal Administrasi Bisnis, 2014

Martono, Nanang. Metode Penelitian Kuantitatif, Jakarta: PT. Raja Grafindo, 2012.
Moeheriono. Pengukuran Kinerja Berbasis Kompetensi. Jakarta: PT RajaGrafindo, 2012.

Munawir. S. Analisa Laporan Keuangan, Edisi Keempat. Yogyakarta: BPFE, 2002.

Nur indriantoro dan bambang Supomo. "Metodologi penelitian Bisnis Untuk Akuntansi dan Manajemen". Edisi pertama, Yogyakarta: Lembaga Penerbit BPFE, 2002.

Prasetyo, Bambang, dkk. Metode Penelitian Kuantitatif: teori dan aplikasi, Jakarta: PT. Raja Grafindo, 2011.

Purna, dkk, "Perekonomian Indonesia Tahun 2008 Tengah Krisis Keuangan Global", artikel diakses pada Tanggal 16 Februari 2017 dari www.setneg.go.id

Rivai, Veithzal, dkk. Commercial Bank Manajement Manajemen Perbankan Dari Teori Ke Praktik. Jakarta: PT. RajaGrafindo Persada, 2013.

Soemitro, Andri Bank dan Lembaga Keuangan Syariah, Jakarta: Kencana, 2009.

Suharsimi, Arikunto. Prosedur Penelitian Komunikasi Suatu Pendekatan Praktek (Jakarta: PT. Rineka Cipta, 2003.

Surabrata, Sumadi. metodologi penelitian, Jakarta: PT. Raja Grafindo, 2011.

Triandara, Sigit dan Totok Budisantosio. Bank dan Lembaga Keuangan Lain, Jakarta: Salemba Empat, 2008.

Wibisono, Dermawan. Manajemen Kinerja: Konsep, Desain, dan Teknik Meningkatkan Daya Saing Perusahaan. Jakarta: Penerbit Erlangga, 2008.

Widyaningrum, Hening Asih, Suhandak, dan Topowijono. Analisis Tingkat Kesehatan Bank Dengan Menggunakan Metode Risk-Based Bank Rating (Studi pada Bank yang terdaftar di Bursa Efek Indonesia dalam IHSG Sub Sektor Perbankan Tahun 2012). Jurnal Admistrasi Bisnis. Vol.9 No.2 April, 2014. 
Yaya Rizal, dkk. Akuntansi Perbankan Syariah Teori dan PraktikKontemporer, Jakarta: Salemba Empat, 2014.

\section{Internet:}

Bank Indonesia. Peraturan Bank Indonesia No.13/1/PBI/2011 tantang Sistem Penilaian Kesehatan Bank umum, Jakarta: BI, 2011.

Bank Indonesia, Peraturan Bank Indonesia Nomor 15/15/PBI/2013 tentang Giro wajib minimum bank umum. Jakarta: BI, 2013.

Bank Indonesia. Surat Edaran No.9/DPbS tahun 2007. Perihal tentang sistem penilaian tingkat kesehatan bank berdasarkan prinsip syariah. Jakarta: BI, 2007.

Bank Indonesia. Sistem Pengawasan Bank.

Bank Syariah Mandiri, Annual Report Profil Perusahaan, databese on-line Available From Bank Syariah Mandiri, Item Profil Perusahaan,

Bank Muamalat Indonesia, Annual Report profile Perusahaan, databese on-line Available From Bank Muamalat Indonesia, Item Profil Perusahaan.

Otoritas Jasa Keuangan. Surat Edaran OJK No. 10/SEOJK.03/2014 Tentang penilaian Tingkat Kesehatan Bank Umum Syariah. Jakarta: OJK,2014.

Otoritas Jasa Keuangan. Statisktik Perbankan Syariah Desember 2016

Otoritas Jasa Keuangan, Statistik Perbankan Syariah Juni 2015.

Otoritas Jasa Keuangan .Pengaturan dan pengawasan bank.

\section{Website:}

http://www.statistikian.com/2014/04/indepen dent-t-test

http://www.bi.go.id/id

http://www.ojk.go.id

http://www.syariahmandiri.co.id/annualrepor $\underline{\mathrm{t}}$

http://www.bankmuamalat.co.id/annualrepor $\underline{\mathrm{t}}$

http://www.statistikian.com/2014/04/indepen dent-t-test. 